7. Komyssarov, V. N. (2000). Sovremennoe perevodovedenye: kurs lektsyi. Moskva: ЭTS. 192 p.

8. Karaban, V. I. (2004). Pereklad anhliiskoi naukovoi i tekhnichnoi literatury. Hramatychni trudnoshchi, leksychni, terminolohichni ta zhanrovo-stylistychni problemy. Vinnytsia: Nova knyha, 576 p.

9. Lakoff, G., Johson, M. (1980). Metaphor We Live By. Chicago; London: The University of Chicago Press, $242 \mathrm{p}$.

10. Kövecses Z. (2002). Metaphor. A Practical Introduction. Oxford; Nev-York: Oxford University Press, 287 p.

11. Kerlot, Kh. (1994). Slovar symvolov. Moskva: «REFL-book», 608 p.

12. Arutiunova, N. D. (1990). Obraz, metafora, symvol v kontekste zhyzny y kultury / otv. red. D. S. Lykhachev. Res Philologica. Moskva; Leningrad: Nauka. p. 71-88.

13. Byrkenbyl, V. (1997). Yazyk intonatsyy, mymyky, zhestov. Sankt-Peterburg: Pyter, $224 \mathrm{p}$.

Матеріал надійшов до редакиї 10.01.2021 p.

УДК 811.111'373.2:161.223.2=030.111=161.2

\title{
Оксана Черняк,
}

кандидат філологічних наук, доцент,

завідувач кафедри іноземних мов та перекладу,

Волинський національний університет імені Лесі Українки,

ORCID ID 0000-0002-3848-0690

Chernyak.Oksana@vnu.edu.ua

DOI https://doi.org/10.29038/2524-2679-2021-01-195-205

\section{ФРАЗЕОЛОГІЧНІ ЗАСОБИ НА ПОЗНАЧЕННЯ ОСУДУ В СУЧАСНІЙ АНГЛІЙСЬКІЙ МОВІ ТА ОСОБЛИВОСТІ ЇХ ПЕРЕКЛАДУ УКРАЇНСЬКОЮ МОВОЮ}

У статті виокремлено й проаналізовано фразеологізми, які виражають негативну оцінку адресата; визначено характеристики особи, щзо найбільше піддаються осуду в англомовному суспільстві і є зафіксованими y фразеологічних одиницях; проаналізовано фразеологізми, котрі позначають діï адресата, які можуть викликати осуд. Фразеологічні засоби є тією частиною лексики, що найбільш виразно виражає емоції та експресії в мові. Вони точно передають емоційний стан самого мовия та тому широко використовуються для позначення його оцінного ставлення до об'єкта. Визначено, що більшість фразеологізмів мають

(C) Черняк О., 2021 
експресивно забарвлене значення, суб'єктивно модальний компонент їхньої семантики сприяє переданню почуттів, емоцій, емоиійних переживань. Виявлено, щзо за структурно-морфологічною ознакою фразеологічні одиниці на позначення осуду можна поділити на дієслівні та субстантивні. Фразеологізми на позначення осуду відображають різний ступінь критики - від легкого несхвалення дій адресата до осуду з образами. Виявлено, щзо в англомовному суспільстві найбільш піддаються осуду такі характеристики особи, як надмірність, багатство, дратівливість, підступність, нечесність у бізнесі тощзо. Виявлено, щзо в англомовному суспільстві найбільш піддаються осуду такі характеристики особи, як надмірність, багатство, дратівливість, nідступність, нечесність у бізнесі тощзо.

У статті розглянуто способи перекладу фразеологічних одиницьь українською мовою та проаналізовано, які способи перекладу найчастіше використовуються під час передання фразеологізмів із негативним знаком оцінки. Труднощзі перекладу англомовних фразеологізмів зумовлені складністю їхньӧ̈ семантичної структури, образним характером, національно-культурною специифікою їхніх значень.

Виявлено, щзо найчастіше під час перекладу фразеологізмів на позначення осуду застосовують описовий переклад, оскільки велика кількість англійських фразеологізмів є безеквівалентними. Водночас нерідко можна знайти фразеологічний аналог або фразеологічний еквівалент під час передання таких фразеологічних одиниць українською мовою.

Ключові слова: фразеологічні одиниці, ідіоми, осуд, описовий переклад, фразеологічний аналог, фразеологічний еквівалент.

\section{1. ВСТУП}

Постановка проблеми. Фразеологізми $\epsilon$ найбільш яскравою та своєрідною частиною словникового складу будь-якої мови, оскільки вони, на відміну від схожих із ними за формою синтаксичних структур, не утворюються відповідно до загальних закономірностей вибору й комбінації слів під час організації висловлення, а відтворюються в мовленні у фіксованому співвідношенні семантичної структури та певного лексико-граматичного складу [1, с. 559]. Особливістю фразеології є те, що це проміжний рівень, який перебуває на стику лексико-семантичного й синтаксичного рівнів, тобто їхні одиниці виникають у синтаксисі, а функціонують на рівних правах зі словом у лексико-семантичній системі $[2$, c. 148$]$.

Актуальність теми зумовлена тим, що фразеологізми відображають духовну та матеріальну динаміку етносу, його національну своєрідність. 
Фразеологічні засоби є тією частиною лексики, яка найбільш влучно й виразно виражає емоції та експресії в мові. Вони точно передають емоційний стан самого мовця й тому широко застосовуються для позначення його оцінного ставлення до об'єкта. Більшість фразеологізмів мають експресивно забарвлене значення, суб'єктивно модальний компонент їхньої семантики сприяє розкриттю почуттів, емоцій, емоційних переживань.

Аналіз останніх досліджень і публікацій. Зазначимо, що проблему перекладу фразеологічних одиниць грунтовно розглянуто в роботах В. С. Віноградова, І. В. Корунця. Такі науковці, як М. С. Зарицький, Р. П. Зорівчак, А. В. Кунін, В. В. Шляхова та ін., широко досліджували питання класифікації фразеологізмів і вивчали практичні аспекти пошуку відповідників в англійській та українській мовах.

Численними й різноманітними з погляду висвітлення різноманітних аспектів фразеологічних одиниць є праці сучасних дослідників. Цікавим $\epsilon$ дослідження I. Ціховського та I. Ковальчук [3] щодо теоретичних аспектів перекладу англійських фразеологізмів у засобах преси. Д. Бєлих і Є. Ковальова [4] проаналізували способи перекладу англійських фразеологічний одиниць у політичному дискурсі. Учені прийшли до висновку, що найкращим способом перекладу політичних фразеологічних одиниць $є$ поєднання калькування та описового перекладу, оскільки переважна кількість цього виду фразеологізмів - це новоутворення політичних діячів або специфічними реаліями.

Структурні особливості адвербіальних фразеологізмів із компонентом на позначення неживої природи в англійській та українській мовах досліджені I. М. Запухляк [5]. І. Денисенко [6] вивчила особливості соматичних фразеологічних одиниць англійської й української мов та проаналізувала розподіл фразеологізмів за соматичним компонентом «hand» i порівняла особливості функціонування та перекладу в українській мові.

Мета дослідження полягає в тому, щоб розглянуті фразеологічні засоби на позначення осуду в сучасній англійській мові й проаналізувати, способи їх перекладу українською мовою. Досягнення мети передбачає виконання таких завдань: виділити та проаналізувати фразеологізми, які виражають негативну оцінку адресата; визначити характеристики особи, що найбільш піддаються осуду в англомовному суспільстві і $€$ зафіксованими у фразеологічних одиницях; проаналізувати фразеологізми, що позначають дії адресата, які можуть викликати осуд, проаналізувати способи їх перекладу українською мовою. 
Методика дослідження. Для пошуку та опису фразеологізмів й ідіом на позначення осуду застосовано метод словникових дефініцій. Дескриптивний метод використано для опису критеріїв диференціації фразеологізмів.

Матеріалом нашого дослідження слугували 196 англійських фразеологічних одиниць, що містять сему «несхвалення» й відібрані методом суцільної із Oxford Idioms Dictionaty for Learners of English [7].

\section{2. РЕЗУЛЬТАТИ ДОСЛІДЖЕННЯ}

Осуд - особливий феномен, це досить багатогранне й суперечливе поняття. Відома біблійна заповідь: «Не судіть та несудимі будете». Осуд можна визначити як вияв негативного, несхвального ставлення до когонебудь, чого-небудь. Осуд вважається одним із найбільших гріхів, оскільки той, хто осуджує, діє так не через любов до ближнього, а через любов до себе. Проте осуд характерний для щоденного життя. Як зазначає Роберт Бакал, «We live in a blaming society. Whether one looks at politics, organizations, or even personal relationships, we, as a society, seem to place great importance on finding some entity or person to blame for almost everything. Political parties blame each other (watch any governmental body meeting or election campaign). Unions blame management. Management blames unions. Spouses blame each other» [8].

Ми розглядаємо осуд як емоційну реакцію, яка виникає під впливом таких емоцій, як гнів, відраза, презирство тощо. Осуд - це комунікативне явище, нерозривно пов'язане 3 параметрами мови та мовлення, їхнього когнітивного й соціального середовищ, феномен зі специфічними властивостями, які не можна повністю пізнати без поглибленого вивчення та систематизації. Когнітивні основи емоційних реакцій полягають у тому, що емоції випливають із когнітивних інтерпретацій об'єктивної реальності. Вони визначаються структурою, змістом й організацією репрезентації знань і процесів, які ними керують [19, с. 44].

Виявлення корпусу лексичних одиниць, що описують i, отже, фіксують різні якісні аспекти осуду, є дуже важливим, оскільки категоризація емоцій здійснюється саме в лексиці, а в реченні вона уточнюється, доповнюється [10, с. 102]. Аналіз словникових дефініцій дає нам змогу зробити висновок, що фразеологізми часто використовуються для позначення осуду в сучасній англійській мові.

Як свідчить ілюстративний матеріал, за структурно-морфологічною ознакою фразеологічні одиниці на позначення осуду поділяються 
на дієслівні та субстантивні. Серед усіх дієслівних фразеологічних засобів із значенням несхвального ставлення мовця до адресата можемо виокремити такі групи:

- критикувати, осуджувати, не схвалювати (have a go (at sb); give $s b$ grief (about/over sth); give sb stick; put sb in the dock; speak think id of sb; shoot sb sth down (in flames); pass judgement (on/about sb/sth) etc.);

- сильно критикувати, не схвалювати (pick, pull, etc sb/sth to bits/pieces; be hard on sb; haul sb over the coals; give sb/get a pasting; give sb a rocket; tear sb/sth to pieces/shreds; take s bto task (about/for/over sth) etc.);

- осуджувати постійно (be on sb's case; throw the book at sb; be/go/keep on at sb (to do sth));

- критикувати сердито (eat sb alive; give sb a piece of your mind; give $s b$ get a roasting; tear $s b$ off a strip; tear a strip off $s b$; be/come down on $s b$ like a ton of bricks etc.);

- критикувати раптово (take a potshot/potshots (at sb/sth));

- насміхатися (make fun of sb/sth (also poke fun at sb/sth); take the mickey/mick (out of sb/sth); take a poke at sb/sth);

- привести в порядок свої справи, а потім критикувати інших (put/set your (own) house in order);

- критикувати несильно (make allowances for sb; damn sb/sth with faint praise; far be it from me to do sth, but...; put it mildly).

Осуд, зафіксований у субстантивних фразеологізмах, може містити:

- факти для обвинувачення (a rod/stick to beat sb with);

- сильну несправедливу критику (a hatchet job (on sb/sth));

- чесну критику (a home truth);

- сильну критику, що змушує адресата поводитися краще (a kick up in the backside (also $a$ kick in the pants));

- захоплення, яке можна зрозуміти також як образу (a backhanded compliment (AmE also a left-handed compliment)).

Особливий інтерес позначають осуджувану особу. Аналіз фактичного матеріалу засвідчив, що в англомовному суспільстві найбільш піддаються

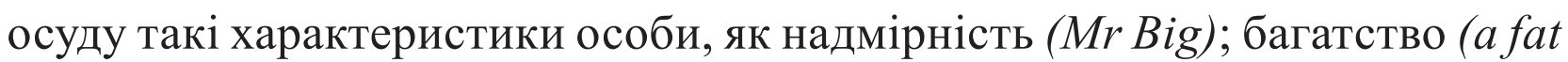
cat); осуджується особа, котра догоджає іншим (a goody-goody; a goody two-shoes); хоче бути в курсі всього (а баск-seat driver); думає, що завжди має рацію ((a) clever Dick (also (a) clever clogs)); без емоцій (a cold fish), дурнувата, дратівлива (an old bat); старомодна (an old fogey/fogy; a stuffed shirt); хвилюється про неважливі речі (old woman); любить підглядати (a Peeping Tom); необережна на дорозі (a road hog); підступна (a snake in 
the grass); без ентузіазму (a wet blanket); нечесна в бізнесі (a wide boy); ординарна (every/any Tom, Dick and/or Harry); багато говорить (all talk (and no action)): хизується своїм розумом (a smart alec/aleck); смішно одягається, щоб виглядати молодшою (mutton dressed (up) as lamb) тощо.

Осуд можуть викликати такі дії адресата:

- поводитися так, як не подобається іншим (be up to your (old) tricks: think you own place);

- викидати гроші на вітер (throw good money after bad);

- обговорювати на людях приватні справи (wash your dirty linen in public);

- приділяти багато уваги незначним речам (split hairs; maкe a song and dance about sth);

- робити щось лише тому, що інші це роблять (like sheep; climb/jump on the bandwagon);

- жебракувати (be/go on the scrounge (for sth));

- бути задоволеним тим, чого досягнув, і не прагнути досягнути більшого (rest on your laurels);

- раптово зацікавитися релігією (get religion);

- повторювати щось, не розуміючи його значення ((learn, repeat, etc. sth) parrot-fashion);

- поводитися по-дурному, щоб інші тебе помітили (make an exhibition of yourself);

- бути підлабузником (curry favour (with sb); touch/tug your forelock);

- поводитися так, ніби ти кращий за інших (be/get above yourself; lord it over sb; with your nose in the air);

- висловлювати свою думку агресивно, навіть не маючи права це робити (lay down the law);

- не бути здатним щось зрозуміти (not know the meaning of the word);

- говорити надто довго й нудно (hold forth (about/on sth));

- роздувати проблему (make a mountain out of a molehill) тощо.

Осуджувана особа може бути розкритикована начальником (be on thecarpet), бути обвинуваченою чи покараною (get it (in the neck); take the rap (for sb/sth)), утратити довіру людей (fall from grace), бути в положенні, коли iii можуть осуджувати (be in the firing line; be for the high jump), усвідомлювати, що іiі можуть осуджувати, і намагатись уникнути цього (cover your back; on/onto the defensive), бути розкритикованою багатьма людьми одночасно (run the gauntlet), бути ображеною критикою (take sth to heart), постійно бути розкритикованою (under siege) тощо.

У проаналізованих нами фразеологізмах зафіксовані також 
невербальні засоби позначення осуду, такі як погляд (a black look; (give sb/get) a dirty look) і міміка (raise your eyebrows (at sth)).

Розглянемо способи перекладу англійських фразеологічних одиниць на позначення осуду українською мовою. Як відомо, основними способами перекладу фразеологічних одиниць $є$ фразеологічний еквівалент, фразеологічний аналог, калькування, описовий переклад, контекстуальна заміна.

Фразеологічний еквівалент - це передача фразеологізмів за допомогою фразеологізмів. Цей спосіб, звісно, є найкращим, оскільки найбільш влучно передає сенс фразеологічної одиниці. Серед проаналізованих фразеологізмів на позначення осуду можна виокремити такі, які можна перекласти за допомогою фразеологічного еквівалента:

- eat sb alive - 3 'їсти живцем;

- be on the carpet - викликати на килим;

- all talk (and no action) - одні балачки;

- dike sheеp - як отара овець;

- rest on your laurels - почивати на лаврах.

Широко використовується переклад за допомогою фразеологічного аналога, тобто в українській мові застосовуються фразеологічні одиниці, котрі мають те саме значення, але побудовані на іншому образі. Наприклад:

- wash your dirty linen in public - виносити сміття (бруд) з хати;

- a fat cat - грошовий мішок;

- a goody-goody - «добрий» дядечко;

- give somebody a rocket - задати жару;

- rant and rave - лютувати аж підскакувати;

- make a mountain out of a molehill - робити 3 мухи слона.

Досить часто використовується описовий переклад під час передання фразеологізмів із семою «несхвалення» українською мовою:

- throw the book at sb - піддавати суворій критиці;

- a backhanded compliment - сумнівний комплімент;

- Mr Big - важлива персона;

- curry favour (with sb) - підлабузнюватися;

- lay down the law - не допускати заперечень;

- an old bat- - зануда;

- a stuffed shirt - чванлива, пихата нікчема;

- a snake in the grass - таємний ворог;

- a back-seat driver - безвідповідальна людина, що дає поради або вказівки; 
- clever Dick - «усезнайко», «розумник»;

- a cold fish - байдужа, холодна людина;

- Peeping Tom - людина, яка любить підглядати;

- wet blanket - людина, яка псує іншим настрій;

- every/any Tom, Dick and/or Harry - будь-хто;

- make a song and dance about sth - піднімати шум;

- haul someone over the coals - дати прочухана.

Отже, як бачимо, найчастіше під час перекладу фразеологізмів на позначення осуду використовують описовий переклад, фразеологічний аналог або фразеологічний еквівалент.

\section{3. ВИСНОВКИ ТА ПЕРСПЕКТИВИ ПОДАЛЬШИХ ДОСЛІДЖЕНЬ}

Отже, фразеологічні засоби широко використовуються для позначення осуду в сучасній англійській мові й поділяють на такі групи:

- фразеологізми, що передають несхвальне ставлення мовця;

- фразеологізми, що характеризують осуджувану особу;

- фразеологізми, що характеризують дії осуджуваної особи;

- фразеологізми, що розкривають підстави для осуду.

Фразеологізми на позначення осуду виражають різний ступінь критики - від легкого несхвалення дій адресата до осуду з образами. Під час дослідження виявлено, що в англомовному суспільстві найбільш осуду піддаються такі характеристики особи, як надмірність, багатство. Осуджується особа, яка догоджає іншим, хоче бути в курсі, думає, що завжди має рацію, без емоцій, дурнувата, дратівлива, старомодна, хизується своїм розумом тощо.

Під час перекладу фразеологізмів на позначення осуду найчастіше використовують описовий переклад, рідше можна знайти випадки перекладу за допомогою фразеологічного аналога або фразеологічного еквівалента.

Фразеологічний склад відображає культурно-історичний досвід народу, його дослідження дає змогу виявити специфічні риси менталітету нації, визначити іiі моральні цінності і пріоритети. Перспективою нашого дослідження $є$ аналіз фразеологічних одиниць на позначення осуду, які трапляються в англійській художній літературі.

\section{СПИСОК ВИКОРИСТАНИХ ДЖЕРЕЛ}

1. Ярцева, В. Н. (1990). Лингвистический энциклопедический словарь. Москва: Сов. энцикл., 685 с. 
2. Кочерган, М. П. (1999). Загальне мовознавство: підруч. для студентів філол. спец. вищ. закл. освіти. Київ. Вид. центр «Академія», 288 с.

3. Ціхоцький, I. В., Ковальчук, I. В. Теоретичні аспекти перекладу англійських фразеологізмів у засобах преси. URL: https:/www. ukrlogos. in.ua/10.11232-2663-4139.04.25.html.

4. Бєлих, Д. І., Ковальова, Є. І. (2018). Особливості перекладу англійських фразеологічних одиниць у політичному дискурсі. Вісник Національного технічного університету «ХНІ». Серія: 88: Актуальні проблеми розвитку українського суспільства, № 4 (1280), c. 88-92. URL.: http://repository.kpi.kharkov.ua/bitstream/KhPI-Press/37235/1/ vestnik_KhPI_2018_4_Belykh_Osoblyvosti_perekladu.pdf

5.Запухляк, I. М. (2020). Структурні особливості адвербіальних фразеологізмів 3 компонентом на позначення неживої природи в англійській та українській мовах. Sciences of Europe, 49, c. 31-35. URL: https://www.researchgate.net/publication/343443217 SIRUKTURNI_OSOBLIVOSTI_ADVERBIALNIH_FRAZEOLOGIZMIV_Z_KOMPONENTOM_NA_POZNACENNA_NEZIVOI_PRIRODI_V_ANGLIJSKIJ_TA_UKRAINSKIJ_MOVAH

6. Денисенко, I. Особливості соматичних фразеологізмів: концепт «HAND» в англійській та українській мовах. URL: http://dspace.tnpu.edu.ua/bitstream/123456789/7705/1/Denysenko.pdf

7. Oxford Idioms Dictionary for Learners of English (2001). Oxford University Press, $465 \mathrm{p}$.

8. Bacal, R. Exorcise Blame In Your Company. URL: http://www.work911.com/articles/blame.htm

9. Приходько, А. И. (2004). Семантика и прагматика оценки в современном английском языке. Запорожье: Запорожский гос. ун-т, 321 с.

10. Бабенко, Л. Г. (1994). Репрезентация эмоций в семантике слова и предложения. Материаль III междунар. семинара "Славянская культура в современном мире (изучение и преподавание в иноязычной аудитории)». Киев: Центр славистики Киев. гос. лингвист. ун-та, с. 101-102.

\section{PHRASEOLOGICAL MEANS DENOTING CONDEMNATION IN MODERN ENGLISH AND FEATURES OF THEIR TRANSLATION INTO UKRAINIAN}

The article identifies and analyzes phraseological units that express a negative assessment of the addressee; the characteristics of the person who is the most susceptible to condemnation in the English-speaking society and are fixed in phraseological units are defined; phraseological units denoting the actions of the addressee that may cause condemnation are analyzed. Phraseological means are the part of vocabulary that most accurately and clearly convey emotions and expressions in the language. They accurately express the emotional state of the speaker and are therefore widely used to indicate his evaluative attitude towards the person. It is determined that the vast majority of phraseological expressions have an expressive colour, the 
subjectively modal component of their semantics promotes the rendering of feelings, emotions, emotional experiences. It is revealed that on a structural- morphological basis phraseological units denoting condemnation can be divided into verbal and substantive. Phraseological units denoting condemnation express varying degrees of criticism; from slight disapproval of the addressee's actions to condemnation with insults. It was found that in the English-speaking society the following characteristics of the person are condemned most often: redundancy, wealth, irritability, insidiousness, dishonesty in business, etc.

The article considers the methods of translation of phraseological units into the Ukrainian language and analyzes which methods of translation are most often used in the rendering of phraseological units with a negative mark. Difficulties in translating English phraseology are due to the complexity of their semantic structure, figurative nature, national and cultural specifics of their meanings. It was found that in the process of translating phraseological units to denote condemnation, descriptive translation is used most often, because a large number of English phraseological units are non-equivalent. At the same time, it is also possible to find a phraseological analogue or phraseological equivalent rendering such phraseological units in the Ukrainian language.

Key words: phraseological units, idioms, condemnation, descriptive translation, phraseological analogue, phraseological equivalent.

\section{REFERENCES}

1. Yartseva, V. N. (1990). Linguistic encyclopedic dictionary. Moskva: Sov. Encycl., $685 \mathrm{p}$.

2. Kochergan, M. P. (1999). General Linguistics, A Textbook for Students of Philological Specialties in Higher Education. Kyiv: Publishing Center «Academy», 288 p.

3. Tsikhovsky, I. V., Kovalchuk I. V. Theoretical aspects of translation of English phraseology in the press. URL: https://www. ukrlogos.in.ua/10.11232-2663-4139.04.25.html.

4. Belykh, D. I., Kovaleva, Ye. I. (2018). Features of translation of English phraseological units in political discourse. Bulletin of the National Technical University «KhPI». Series: 88: Actual problems of development of the Ukrainian society, 4 (1280), p. 88-92. URL.: http://repository.kpi.kharkov.ua/bitstream/KhPI-Press/37235/1/vestnik_KhPI_2018_4_Belykh_Osoblyvosti_perekladu.pdf

5. Zapukhlyak, I. M. (2020). Structural features of adverbial phraseology with a component for the designation of inanimate nature in English and Ukrainian. Sciences of Europe, 49, 31-35. URL: https://www.researchgate.net/publication/343443217_SIRUKTURNI_ OSOBLIVOSTI_ADVERBIALNIH_FRAZEOLOGIZMIV_Z_KOMPONENTOM_NA_ POZNACENNA_NEZIVOI_PRIRODI_V_ANGLIJSKIJ_TA_UKRAINSKIJ_MOVAH

6. Denisenko, I. Features of somatic phraseology: the concept of «Hand» in English and Ukrainian. URL: http://dspace.tnpu.edu.ua/bitstream/123456789/7705/1/Denysenko.pdf 
7. Oxford Idioms Dictionary for Learners of English (2001). Oxford University Press, $465 \mathrm{p}$.

8. Bacal, R. Exorcise Blame In Your Company. URL: http://www.work911.com/articles/blame.htm

9. Prikhodko, A. I. (2004). Semantics and pragmatics of evaluation in modern English. Zaporozhye: Zaporozhye State University, $321 \mathrm{p}$.

10. Babenko, L. G. (1994). Representation of emotions in the semantics of words and sentences. Materials III International, seminar «Slavic culture in the modern world (study and teaching in a foreign language audience)». Kyiv: Center for Slavic Studies of Kiev State Linguistic University, 101-102.

Матеріал надійшов до редакиіï 06.01.2021 p. 